\begin{tabular}{|c|c|c|}
\hline \multirow{4}{*}{$\begin{array}{r}\text { Case Reports in } \\
\text { Gastroenterology }\end{array}$} & \multirow{2}{*}{\multicolumn{2}{|c|}{ Case Rep Gastroenterol 2019;13:214-218 }} \\
\hline & & \\
\hline & $\begin{array}{l}\text { DOI: 10.1159/000500067 } \\
\text { Published online: April 23, } 2019\end{array}$ & $\begin{array}{l}\text { (c) } 2019 \text { The Author(s) } \\
\text { Published by S. Karger AG, Basel } \\
\text { www.karger.com/crg }\end{array}$ \\
\hline & $\begin{array}{l}\text { This article is licensed under } \\
\text { International License (CC BY-NC } \\
\text { Usage and distribution for comm }\end{array}$ & $\begin{array}{l}\text { nons Attribution-NonCommercial } 4.0 \\
\text { ger.com/Services/OpenAccessLicense). } \\
\text { uires written permission. }\end{array}$ \\
\hline
\end{tabular}

\title{
An Esophageal Ulcer Associated with a Thoracoabdominal Aortic Aneurysm
}

\author{
Atsuto Kayashima Hideki Mori Anna Okuzawa Yoko Kubosawa \\ Yuichiro Hirai Satoshi Kinoshita Yoshihiro Nakazato Ai Fujimoto \\ Masahiro Kikuchi \\ Department of Gastroenterology, National Hospital Organization Tokyo Medical Center, \\ Tokyo, Japan
}

\section{Keywords}

Esophageal ulcer - Thoracoabdominal aortic aneurysm - Aortoenteric fistula .

Aortoesophageal fistula

\begin{abstract}
An aortoesophageal fistula, an abnormal anatomical communication between the aorta and the esophagus, is a rare cause of upper gastrointestinal bleeding. The mortality rate of patients with this condition is very high. A 77-year-old man, who had undergone endovascular aortic repair for a ruptured abdominal aortic aneurysm, developed melena. An upper gastrointestinal endoscopy was performed. This detected an esophageal ulcer, which had the potential to develop into an aortoesophageal fistula. Therefore, thoracic endovascular aortic repair was performed on the following day. Thereafter, the course was uneventful. We encountered a rare case of an esophageal ulcer associated with a thoracoabdominal aortic aneurysm before it developed into an aortoesophageal fistula.




\section{Introduction}

Major vascular lesions, such as aortic aneurysms, and gastrointestinal lesions, such as gastrointestinal ulcers, influence each other, which can cause major bleeding. An aortoenteric fistula (AEF), an abnormal anatomical communication between the aorta and digestive tract, is a rare cause of upper gastrointestinal bleeding [1]. There are 2 types of AEFs: primary AEFs (PAEFs) and secondary AEFs (SAEFs) [2]. SAEFs occur due to bacterial infection of artificial blood vessels after artificial revascularization surgery, while PAEFs are caused by other factors. PAEFs are much rarer than SAEFs. We report a case with an aortoesophageal fistula as a type of PAEF.

\section{Case Report}

A 77-year-old man, who had received chemoradiotherapy for early esophageal cancer 11 years previously, was admitted to the emergency room at our hospital with a ruptured abdominal aortic aneurysm. Endovascular aortic repair was performed on the same day. After 34 days, the patient developed melena and an upper gastrointestinal endoscopy was performed. An esophageal ulcer, which presented as a protruded lesion with a depression, was observed immediately above the gastroesophageal junction (Fig. 1). Urgent contrast-enhanced computed tomography performed on the same day revealed that this site coincided with the position of the thoracoabdominal aortic aneurysm (Fig. 2). Esophageal excretion by the aneurysm was diagnosed as the cause of ulceration.

Thoracic endovascular aortic repair (TEVAR) was performed on the following day to prevent bleeding and formation of an aortoesophageal fistula. Thereafter, rehemorrhage was not observed and the course was uneventful. An upper gastrointestinal endoscopy performed 57 days after TEVAR revealed that the esophageal ulcer was healing (Fig. 3).

\section{Discussion}

An aortoesophageal fistula is a rare type of AEF. For anatomical reasons, such fistulas predominantly develop in the duodenum (83\%), especially in the horizontal part (57\%) [3]. Most PAEFs (80\%) involve aortic aneurysms. Other causes include gastrointestinal ulcers and foreign bodies, diverticulitis, malignant tumors, iatrogenesis, and irradiation.

In this case, who had previously received chemoradiotherapy for esophageal cancer, expansion and pulsatile excretion of an aortic aneurysm together with a penetrating atherosclerotic ulcer were considered to be involved in esophageal ulceration [4].

The mortality rate of patients with PAEFs is almost $100 \%$ without intervention and 1893\% if treatment is performed [5]. However, there is poor awareness that gastrointestinal bleeding can be caused by AEFs, and this condition is difficult to diagnose despite being fatal.

The 3 major symptoms of AEFs are hematemesis, abdominal pain, and a pulsatile abdominal mass; however, only $11-28 \%$ of cases display all these symptoms [6]. Although gastrointestinal endoscopy may be performed first in patients with AEFs due to gastrointestinal bleeding, its diagnosis rate is low at around $25 \%$. The usefulness of contrast-enhanced computed tomography in this context was recently highlighted, with a diagnosis rate of 30-61\% [7]. Therefore, contrast-enhanced computed tomography should be performed first when an AEF is suspected. 
Intermittent bleeding, called herald bleeding, occurs prior to mass bleeding in $94 \%$ of cases with AEFs [8]. Vasospasm and thrombus formation occur due to a temporary decrease in blood pressure and a local decrease in blood flow in the fistula, which temporarily blocks the fistula and hemostasis. Thereafter, restoration of normotensive pressure upon closure of the fistula causes displacement of the thrombus, leading to major bleeding. Therefore, it is difficult to diagnose AEFs in such cases using computed tomography and endoscopy [9]. In the current case, melena was considered to be caused by herald bleeding, and treatment was performed before major bleeding occurred.

In summary, AEFs are a potential cause of gastrointestinal bleeding, and this is considered to be an important case report.

\section{Statement of Ethics}

The authors have no ethical conflicts to disclose. The patient agreed to the publication of his medical data. All authors were involved in the patient's care.

\section{Disclosure Statement}

The authors have no conflicts of interest to declare.

\section{Funding Sources}

There were no funding sources.

\section{References}

1 Busuttil SJ, Goldstone J. Diagnosis and management of aortoenteric fistulas. Semin Vasc Surg. 2001 Dec;14(4):302-11.

2 Kokatnur L, Rudrappa M. Primary aorto-esophageal fistula: great masquerader of esophageal variceal bleeding. Indian J Crit Care Med. 2015 Feb;19(2):119-21.

3 Sweeney MS, Gadacz TR. Primary aortoduodenal fistula: manifestation, diagnosis, and treatment. Surgery. 1984 Sep;96(3):492-7.

4 Puccio F, Pandolfo G, Chiodini S, Benzi F, Solazzo M. Primary aorto-duodenal fistula as a late complication of radiotherapy: report of a case and review of the literature. Case Rep Gastroenterol. 2008 Sep;2(3):415-23.

5 Lemos DW, Raffetto JD, Moore TC, Menzoian JO. Primary aortoduodenal fistula: a case report and review of the literature. J Vasc Surg. 2003 Mar;37(3):686-9.

6 Song Y, Liu Q, Shen H, Jia X, Zhang H, Qiao L. Diagnosis and management of primary aortoenteric fistulas experience learned from eighteen patients. Surgery. 2008 Jan;143(1):43-50.

7 Wood A, Bendjelid SM, Bendjelid K. Primary aortoenteric fistula: should enhanced computed tomography be considered in the diagnostic work-up? Anesth Analg. 2005 Oct;101(4):1157-9.

8 Saers SJ, Scheltinga MR. Primary aortoenteric fistula. Br J Surg. 2005 Feb;92(2):143-52.

9 Matsubara Y, Ohta T, Tatsumi R, Takasaka T, Sakamoto J, Sato R, et al. Two cases of aortoenteric fistula with gastrointestinal bleeding. Nihon Shokakibyo Gakkai Zasshi. 2016;113(11):1887-93. 


\section{Case Reports in Gastroenterology}

\begin{tabular}{l|l}
\hline Case Rep Gastroenterol 2019;13:214-218 \\
\hline DOI: 10.1159/000500067 & $\begin{array}{l}\text { @ 2019 The Author(s). Published by S. Karger AG, Basel } \\
\text { www.karger.com/crg }\end{array}$ \\
\hline
\end{tabular}

Kayashima et al.: An Esophageal Ulcer Associated with a Thoracoabdominal Aortic Aneurysm

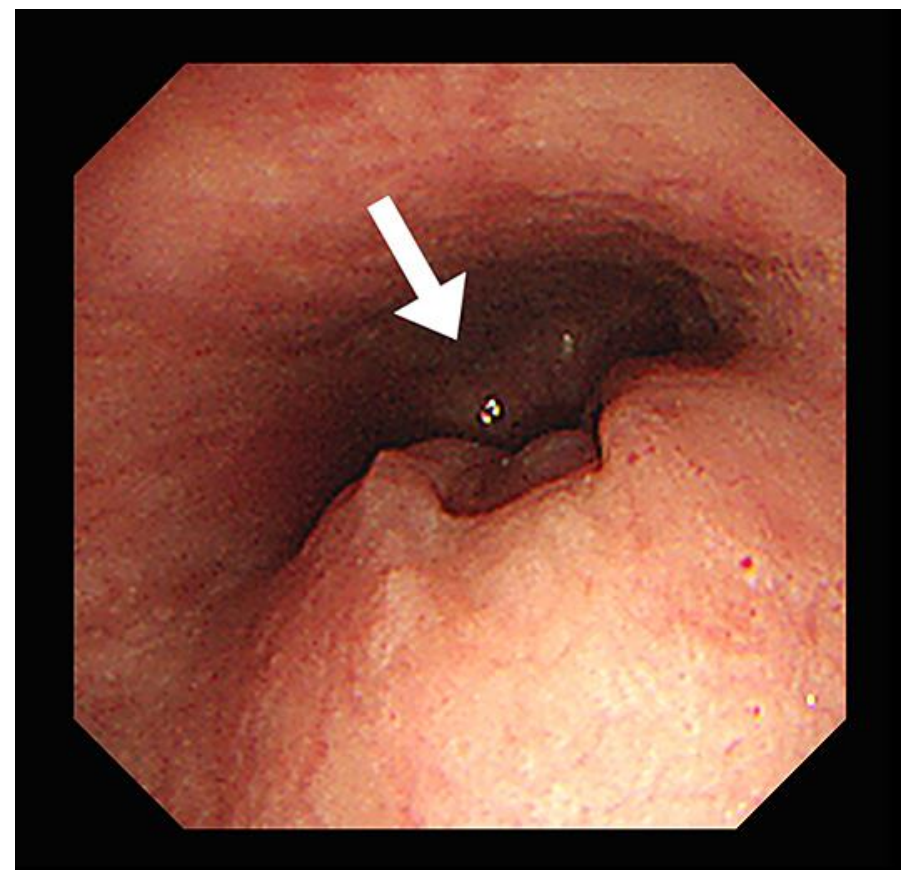

Fig. 1. Esophagogastroduodenoscopy performed on the day that melena developed, showing an esophageal ulcer above the gastroesophageal junction.

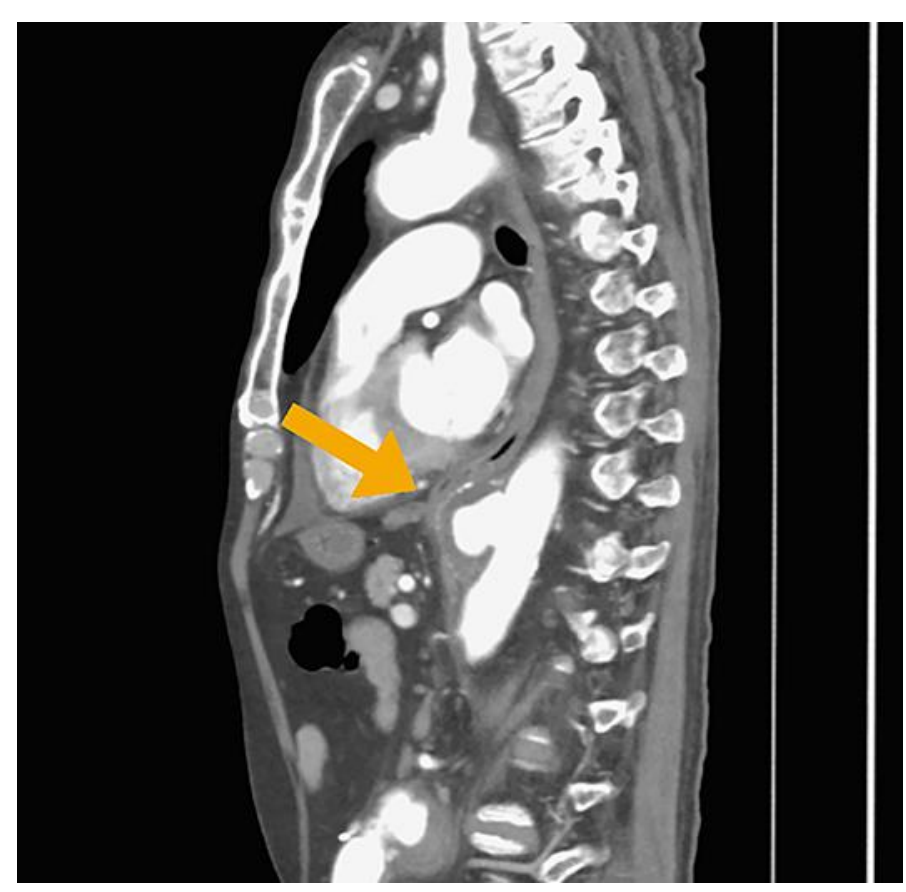

Fig. 2. Contrast-enhanced computed tomography performed on the day that melena developed. The position of the thoracoabdominal aortic aneurysm coincided with that of the esophageal ulcer. 


\section{Case Reports in Gastroenterology}

\begin{tabular}{l|l}
\hline Case Rep Gastroenterol 2019;13:214-218 \\
\hline DOI: 10.1159/000500067 & $\begin{array}{l}\text { @ 2019 The Author(s). Published by S. Karger AG, Basel } \\
\text { www.karger.com/crg }\end{array}$ \\
\hline
\end{tabular}

Kayashima et al.: An Esophageal Ulcer Associated with a Thoracoabdominal Aortic Aneurysm

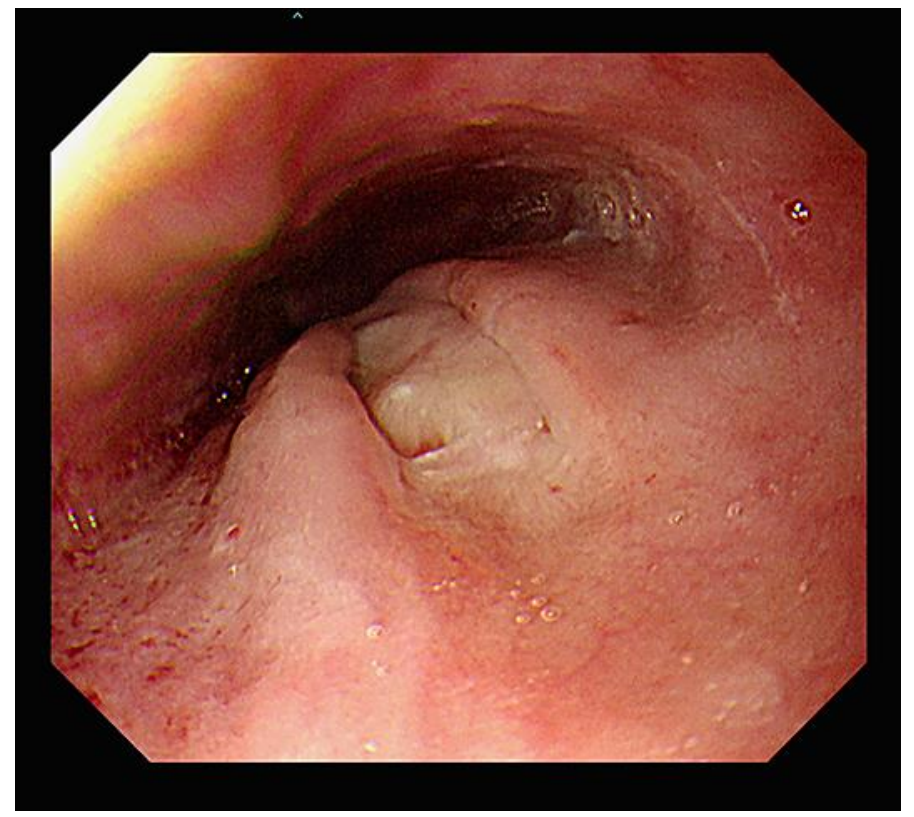

Fig. 3. Esophagogastroduodenoscopy performed 57 days after TEVAR, showing healing of the esophageal ulcer. 